The University of San Francisco

USF Scholarship: a digital repository @ Gleeson Library | Geschke Center

Nursing and Health Professions Faculty Research and Publications

2005

\title{
Using a Collaborative Learning Method to Enhance Mastery of Pathophysiology Content
}

Margaret M. Hansen EdD, MSN, RN

University of San Francisco, mhansen@usfca.edu

M Fonteyn

Follow this and additional works at: http://repository.usfca.edu/nursing_fac

Part of the Education Commons, and the Medicine and Health Sciences Commons

\section{Recommended Citation}

Maag [Hansen]M, Fonteyn M. Using a collaborative learning method to enhance mastery of pathophysiology content. J Nurs Educ. 2005 Sep;44(9):435-6.

This Article is brought to you for free and open access by the School of Nursing and Health Professions at USF Scholarship: a digital repository @ Gleeson Library | Geschke Center. It has been accepted for inclusion in Nursing and Health Professions Faculty Research and Publications by an authorized administrator of USF Scholarship: a digital repository @ Gleeson Library | Geschke Center. For more information, please contact repository@usfca.edu. 
Using a Collaborative Learning Method to Enhance Mastery of

Pathophysiology Content

\author{
By \\ Margaret Maag, Ed.D., R.N. \\ Assistant Professor \\ University of San Francisco \\ School of Nursing \\ San Francisco, CA 94117-1080 \\ maag@usfca.edu \\ And \\ Marsha Fonteyn, Ph.D., R.N. \\ Nurse Scientist \\ Dana Farber Cancer Institute \\ The Phyllis F. Cantor Center \\ Research in Nursing \& Patient Care Services \\ 44 Binney Street G220 \\ Boston, MA 02115-6084 \\ Marsha_Fonteyn@dfci.harvard.edu
}


Using a Collaborative Learning Method to Enhance Mastery of Pathophysiology

Content

Meeting learning objectives with innovative educational techniques can be challenging, and requires attention to learning theories and instructional technology; but the benefits gleaned from creative teaching strategies are rewarding for both students and teachers. Student centered learning environments that engage learners and encourage active participation may result in improved critical-thinking, problem-solving, and communication skills.

Nursing students enrolled in an undergraduate pathophysiology course requested that more case studies be presented during classroom instruction, to help improve their thinking skills and enhance clinical application of complex concepts. Case studies have been shown to be effective tools to address these needs, and their use in medical and legal pedagogical circles dates back to the late 1800s (Tomey, 2003). The use of asynchronous computer mediated learning $(\mathrm{CML})$, via electronic conferencing, fosters students' ability to collaborate and communicate in an active learning environment (Babenko-Mould, Andrusyszyn, \& Goldenberg, 2004). The Institute of Medicine (2003) has proposed that health professionals develop competencies in effective collaboration, communication, and the use of current technology. With this in mind, a blended behaviorist, cognitivist, and constructivist learning approach, incorporating the use of student authored case studies and asynchronous CML, was developed for use with nursing students enrolled in an undergraduate "Introduction to Pathophysiology" course. At the beginning of the course, students were asked to identify a learning partner to work with on specific course assignments throughout the 
academic semester. The assignments consisted of student-dyads working together to review and respond to questions about each other's case studies. Each student created three authentic case studies related to select class topics (e.g. fluid and electrolyte imbalances) during a 15-week semester. After crafting a case study, each student wrote two multiple-choice and two short-answer questions pertaining to the case. Next, the student posted this assignment on a secure online bulletin board, then invited his or her partner to read the case study and answer the questions, which were posted for class members to view electronically. The course instructor created a heading on an open source bulletin board system (BBS) written in a server side programming language (PHP) to organize and announce students' postings throughout the semester. Utilizing a database backend (My SQL), the BBS allowed students and instructors to post, search, and add new topics to the course discussion board in a timely and organized manner.

Throughout the semester, the instructor also presented case studies, with accompanying multiple-choice questions in class (on PowerPoint slides) and posed critical-thinking questions that students actively discussed and answered during brief intentional pauses in the lecture. This helped students to understand how to complete the case study assignments.

As students submitted their case study assignments, the instructor read each, in turn, along with their partner's responses, and provided constructive feedback via an electronic "private message" (PM) system on the BBS. This electronic writing area allowed the student and instructor to choose "emoticons" (animated facial expressions) and a palette of colorful fonts to use when communicating asynchronously. The 
students expressed appreciation for this feedback, which seemed to enhance their selfefficacy. Students described how the development of the case studies and subsequent questions served as an advanced organizational tool for preparing for exams and classroom activities. One student reported: "The case study assignments have been very interesting and helpful to me. The reason for this is I had to pick an illness and write a story and questions related to the illness. This helped me remember part of the definition or symptoms of the illness. Writing a story made this more personal since I had to be creative in making up the story and questions. We also had the opportunity to read our classmates' stories and answer their questions. This was great. Many students think of concepts differently, so this made me look up the symptoms related to their stories and answer their questions" (quote used with permission from the student). A sampling of students' case studies may be viewed at http://www.maagnursing.com/cases (permission was obtained from the students prior to posting their case studies at this site).

A sense of a learner "connectedness" emerged from this authentic learning assignment, as evidenced by students getting better acquainted with one another, supporting each other's learning success, and challenging their peers with well-written case studies and pertinent questions. This interactive CML experience engaged students to think critically, construct new knowledge, be reflective, improve their writing skills, and share creative ideas in a challenging course. A qualitative study is planned, to examine students' learning experiences and attitudes toward a CML environment. Faculty teaching in didactic, learning labs, and clinical settings could use this type of learning activity to enhance students' critical thinking and problem solving skills. Faculty 
might also consider asking expert clinicians to contribute case studies and questions, for which they would be given continuing education units or an honorarium. 


\section{References}

Babenko-Mould, Y., Andrusyszyn, M., \& Goldenberg, D. (2004). Effects of computer-based clinical conferencing on nursing students' self-efficacy. The Journal of Nursing Education, 43, 149-155.

Institute of Medicine (2003). Health professions education: A bridge to quality. Washington, DC: The National Academies Press.

Tomey, A. M. (2003). Learning with cases. The Journal of Continuing Education in Nursing, 34, 34-38. 